\title{
The language situation in Buryat Republic
}

DOI: $10.31551 / 2410-2725-2018-4-2-302-320$

\section{Dyrkheeva Galina Alexandrovna}

Doctor of Philology, Professor, Chief researcher of The Institute for Mongolian, Buddhist and Tibetan Studies of the Siberian Branch of the Russian Academy of Sciences. Russia, 670047, Ulan-Ude, Sakhjyanova St., 6. E-mail: an5dag1@mail.ru

\begin{abstract}
The article is about the features of language situation in Buryat Republic. Statistical data on national structure, recognition of mother tongue, knowledge of different languages are submitted. The main attention is paid to the Buryat language - one of the state languages of Buryat Republic: history of its development (problems of graphics, literary form of language), current state, specifics of language legislation, problems of its realization. The characteristics of its functioning in various official and informal spheres are briefly presented.
\end{abstract}

Key words: Buryats; Buryat language; state language; graphics of the Buryat language; language situation.

\section{Бурятия Республикасындағы тіл жағдайы}

\section{Дырхеева Галина Александровна}

фрилология ғылымдарының докторы, профессор, моңғолтану, РҒА СБ буддология және тибетология институтының бас ғылыми қызметкері. Ресей, 670047, Улан-Удэ қ, Сахъянова к, 6 үй. E-mail: an5dag1@mail.ru

Аңдатпа. Мақала Бурятия Республикасындағы тілдік жағдайдың ерекшеліктеріне арналған. Ұлттық құрамға байланысты статистикалық деректер, бір немесе бірнеше тілді меңгеру, ана тілі ретінде тілді тану ұсынылған. Негізгі назар Бурятия Республикасының мемлекеттік тілдерінің бірі - бурят тіліне: даму тарихы (графикалық мәселелер, тілдің әдеби формасы), қазіргі жағдайы, тілдік заңнаманың ерекшелігі, оны жүзеге асыру мәселесіне аударылады. Түрлі ресми және бейресми салаларда оның жұмыс істеу ерекшеліктері қысқаша баяндалған. Түрлі ресми және бейресми салаларда оның жұмыс істеу ерекшеліктері қысқаша баяндалған.

Кілт сөздер: буряттар; бурят тілі; мемлекеттік тіл; бурят тілінің графикасы; тіл жағдайы.

\section{Языковая ситуация в Республике Бурятия}

\section{Дырхеева Галина Александровна}

доктор филологических наук, профессор, главный научный сотрудник Института монголоведения, буддологии и тибетологии СО РАН. Россия, 670047, г. Улан-Удэ, ул. Сахьяновой, 6. E-mail: an5dag1@mail.ru

\begin{abstract}
Абстракт. Статья посвящена особенностям языковой ситуации в Республики Бурятия. Представлены статистические данные по национальному составу, признанию языка родным, владению тем или иным языком. Основное внимание уделено бурятскому языку - одному из государственных языков Республики Бурятия: истории его развития (проблемы графики, литературной формы языка), современному состоянию, специфике языкового законодательства, проблеме его реализации. Кратко представлена характеристика его функционирования в различных официальных и неофициальных сфрерах.

Ключевые слова: буряты; бурятский язык; государственный язык; графрика бурятского языка; языковая ситуация.
\end{abstract}




\title{
әОЖ/ УДК 81(571.54)
}

\section{Языковая ситуация в Республике Бурятия 1}

\author{
Г.А. Дырхеева
}

Республика Бурятия образована в 1923 г., находится на юге Восточной Сибири Российской Федерации. Граничит с Иркутской областью, Республикой Тыва, Забайкальским краем, имеет государственную границу с Монголией. По данным переписей населения, в 1926 г. население республики составляло 489609 чел., в 1939 г. - 545766, 1959 г. - 673326, 1970 г. - 812251, 1979 г. 899398, 1989 г. - 1038252, 2002 г. - 981238, 2010 г. - 972021, по данным Госкомстата, в 2013 г. - 971810 чел.

По данным переписи 2010 г., в РБ проживали представители более 100 национальностей, из них русские - 630783 (66,1\%), буряты - 286839 (30\%), украинцы - $5654(0,6 \%)$, татары - $6813(0,7 \%)$, сойоты - $3579(0,4 \%)$, эвенки $2974(0,3 \%)$. Основная масса носителей бурятского языка проживает в Российской Федерации, из них на территории РБ - 61\%, а в сумме в трех бурятских субъектах РФ (Республике Бурятия, национальных округах Иркутской области и Забайкальского края) - 83,5\%. За рубежом они компактно проживают в Монголии (около 60 тысяч человек) и Китае (около 6000 человек).

Республика Бурятия отличается высокой степенью неоднородности расселения. На ее территории расположено шесть городов, 17 поселков городского типа и 273 сельских поселения. В этническом плане она гетерогенна, преимущественно здесь проживают русские и буряты, которые составляют подавляющее большинство населения $(96,1 \%)$. На данный момент в 7 (из 22) районах большинство составляют буряты: Курумканский $(65,4 \%)$, Закаменский $(63,2 \%)$, Тункинский $(62,8 \%)$, Кижингинский $(59,1 \%)$, Еравнинский $(54,1 \%)$, Иволгинский $(52,3 \%)$ и Окинский район (49\%). По территории республики они расселены неравномерно, чему способствуют привычные места обитания и традиционный уклад жизни в быту и в хозяйстве. В русском расселении можно выделить 4 ареала: транссибирская магистраль, побережье Байкала, БайкалоАмурская магистраль и ареал проживания семейских ${ }^{2}$. Они остаются в численном преимуществе во всех городских поселениях.

Что касается остальных национальностей, то наиболее многочисленными из них являются татары, расселившиеся в основном в «бурятских» районах, а также украинцы, которые составляют с русскими единое этническое пространство. Эвенки и сойоты, считающиеся автохтонными народами, живут в отдаленных и малоосвоенных районах республики. Сойоты наиболее компактно проживают в Окинском районе, климатические условия и ландшафт которого повлияли на хозяйственную деятельность данного этноса. Эвенки, частично ассимилированные, проживают в Баунтовском (5,4\%), Северобайкальском $(4,5 \%)$ и Курумканском $(2,3 \%)$ районах, занимаются в основном оленеводством, охотой и рыболовством. Согласно Концепции государственной национальной политики РБ, коренными народами республики являются русские, буряты и эвенки.

\footnotetext{
Работа выполнена в рамках государственного задания Федерального государственного бюджетного учреждения науки «Институт монголоведения, буддологии и тибетологии Сибирского отделения Российской академии наук (ИМБТ СО РАН)» по проекту XII.193.1.5. Ментальность монгольских народов в зеркале языка, номер госрегистрации № AAAA-A17-117021310266-8 ("Mentality of the Mongolian peoples in the mirror of language").

${ }^{2}$ Семейские - старообрядцы, этнографическая группа русских Забайкалья.
} 
По данным переписи 2010 г. городское население в республике составляло $58,4 \%$, сельское - 41,6\%. Основная масса городского населения проживает в г. Улан-Удэ, столице республики (из 447,4 тыс. - 404,4 тыс. по переписи 2010 г.). Город Улан-Удэ построен в конце XVII в., на протяжении почти трех столетий являлся оплотом российской урбанизации. Даже в начале $\mathrm{XX}$ в. численность бурятского населения в городе (в 1904 г. - 90 чел., 10 юрт) уступала не только русскому населению, но даже евреям, полякам и китайцам. В середине XX в., с развитием образования, науки и культуры, число бурят в столице начало увеличиваться. На сегодня их численность в Улан-Удэ составляет около 117 тыс. чел., это примерно 30 \% от общего числа жителей города. По данным статистического сборника в 1994 году родным из них признали бурятский язык $78,3 \%$, русский - 21,7\%. За 50 лет число бурят в столице Бурятии увеличилось более чем в 6 раз, с 5-7\% в 1950-60-х гг. до почти 30\% в 2000-е гг. Доля бурят среди улан-удэнцев продолжает расти. Этому способствует приток сельского (в большинстве своем бурятского) населения в пригороды Улан-Удэ и отток русского населения за пределы Бурятии.

Основными компонентами языковой ситуации Республики Бурятия являются русский и бурятский языки. В целом для республики характерна несбалансированная социально-коммуникативная система с набором языков, неравнозначных в фрункциональном отношении: от русского языка, который применяется во всех сорерах общения, до украинского, эвенкийского, немецкого и других языков, которые используются только в быту. Объем общественных функций, выполняемых бурятским языком незначителен, сфер социальнокультурной жизни, в которых бурятский язык употребляется достаточно интенсивно, немного, социальная база литературного бурятского языка постепенно сокращается.

Русский язык признан государственным на всей территории Российской Федерации как язык межнационального общения. В Бурятии он бытует с XVII в., однако наиболее широкое распространение и функционирование он получил в XX в. и в настоящее время он употребляется во всех сфрерах общественно-политической, хозяйственной и культурной жизни республики, постепенно вытеснив бурятский язык, даже в районах с преобладающим бурятским населением. Формы его бытования: от литературной, разговорной и до диалектов и говоров. Можно отметить, что в Восточной Сибири преимущественно распространены говоры северорусского происхождения.

Бурятский язык - один из основных монгольских языков, который как самостоятельный сложился в околобайкальском регионе. Существенные перекосы в национально-языковой жизни страны в 1930-1980-е гг. привели к тому, что язык утратил свои общественные функции, и современная языковая ситуация характеризуется тем, что наиболее острой и насущной сегодня признается проблема поддержки и сохранения именно бурятского языка. Пока он остается конкурентоспособным только в семейно-бытовой сфере.

По данным переписи 1986 г., родным признали бурятский язык 89,4\% жителей бурятской национальности республики. В 2010 г. - 81,8\%. Однако, фрактически, как показывают социолингвистические исследования ${ }^{3}$, уровень

\footnotetext{
${ }^{3}$ В отделе языкознания Института монголоведения, буддологии и тибетологии СО РАН проводится постоянный мониторинг изменения языковой ситуации в республике и по возможности в округах. Основные результаты этих обследований изложены в работах: Дырхеева Г.А., Будаев Б.Ж., Бажеева Т.П. Бурятский язык: современное состояние (социолингвистический аспект). - Улан-Удэ, БНЦ СО РАН, 1999; Дырхеева Г.А. Бурятский язык в условиях двуязычия: проблемы функционирования и перспективы развития. -Улан-Удэ, БНЦ СО РАН, 2002; Сундуева Д.Б. Бурятско-русское двуязычие в Агинском бурятском автономном округе: социолингвистический аспект. - Чита, 2005.
} 
владения родным языком гораздо ниже и можно констатировать постоянное ухудшение ситуации по разным показателям, в том числе признания того или иного языка родным, в среднем на 3\% каждое десятилетие.

Согласно выделенной В.Ю. Михальченко (Михальченко 2009: 37) функциональной типологии, бурятский язык относится к третьему типу среднеразвитых языков.

По переписи 2002 г., когда впервые в вопросник был включен вопрос о владении языками, 98,6\% граждан РБ ответили, что владеют русским языком. Вторым государственным языком республики, бурятским, владели 23,6 \% (при этом доля бурят в РБ составляла 27,8\%, т.е., можно сказать, что с небольшой долей погрешности около 4\% бурят не владели родным языком). Из других языков наиболее распространенными являлись английский - 3,8\%, немецкий - 1,2\%, украинский - 0,6\%, татарский - 0,4\%, фрранцузский - 0,4\%, китайский - 0,2\%.

В 2010 г. доля положительно ответивших на вопрос о владении русским языком выросла с 98,6\% до 99,7\% от ответивших на вопрос о владении языками. Доля же положительно ответивших на вопрос о владении бурятским языком существенно снизилась - до 13,7\%. Каждым из трех языков украинским, китайским, татарским - владеют около 0,3\% опрошенных.

В 1989 г. 99,9\% русских РБ назвали свой язык своим родным языком, 146 чел. (0,02\%) ответили, что владеют им как вторым языком, 2048 (0,3\%) ответили, что владеют бурятским как вторым языком, при этом 111 чел. признали его родным. 89,4\% бурят признали родным бурятский язык, при этом 73,6 \% своим вторым языком признали русский язык («свободно владею вторым языком»). 4002 (1,6\%) чел. ответили, что владеют своим бурятским языком как вторым. Третья самая многочисленная этническая группа - украинцы (22868 чел.). Половина из них признала родным язык своей национальности, а вторая половина родным признала русский язык, 18 чел. ответили, что владеют вторым бурятским языком. Более половины $(56,4 \%)$ татарского населения республики признала родным свой татарский язык, 42,5\% - русский, 110 чел. (около 1\%) бурятский, при этом владеют им как вторым 184 чел. (1,2\%). Почти половина эвенков (из 1679 человек) признали родным русский язык, 74 чел. - бурятский. Русским языком как вторым из них владели более 45\%, бурятским - около $3 \%$.

По данным переписи 2002 г., бурятским языком в республике владели 81,4\% бурят, 0,7\% русских, 10,2\% татар, 95,8\% сойотов, 19,6\% эвенков, 0,4\% украинцев. Эвенкийским языком владели эвенки - 32,4\%.

Существенное снижение доли владеющих бурятским языком наблюдается в 2010 г. не только среди самих бурят (43,6\%), но и среди русских - 0,4\%, татар - 6,6 \%, 92,3\% сойотов, 4,2\% эвенков, 0,2\% украинцев.

Таким образом, демографическая мощность русского языка в Бурятии за прошедшее десятилетие выросла, бурятского - существенно снизилась.

По данным переписи 2002 г., в Бурятии 13238 (1,3\% всего населения РБ) человек ответили, что не владеют русским языком, из них около 1\% (978 человек) русских, более 4\% (10585 человек) бурят, 38\% китайцев, более 20\% корейцев, около $9 \%$ сойот, более $1 \%$ эвенков.

В 2010 г., как отмечено выше, демографическая мощность русского языка выросла: только 102 чел. (менее двух сотых одного процента) русской национальности, 2315 бурят (0,75\%), татары - семь человек, украинцы - три, сойоты - 284, эвенки - один чел., ответили, что не владеют русским языком,

Таким образом, демографическая мощность русского языка в Бурятии существенно выше, чем у второго государственного языка республики бурятского. Бурятский язык включен в Красную книгу исчезающих языков. 
Очевидно, что динамика развития наиболее распространенного в Бурятии бурятско-русского двуязычия - пока не в пользу бурятского языка. В настоящее время соотношение бурятский - русский язык характеризуется тем, что оба языка имеют одинаковый юридический статус, но функциональные возможности, бурятского языка значительно ниже и достаточно не развиваются. Бурятско-русское двуязычие, в основном, характеризуется функциональным распределением языков, когда русский язык соотносится с нетрадиционными для бурят сферами деятельности, а родной используется в повседневнобытовом общении.

Взаимодействие языков способствует развитию различных типов бурятскорусского билингвизма. Среди выделяемых обычно типов билингвизма (Bepeщагин 1969: 80-82) для бурят наиболее характерными являются активная субординативная форма с соблюдением норм обоих языков с незначительной интерференцией и репродуктивная форма, когда используются преимущественно русский или бурятский язык со вторым языком на уровне репродуктивного билингвизма. В последние годы все более увеличивается число носителей пассивного билингвизма, воспринимающих бурятский язык, но воспроизводящих его с трудом. К числу тех, кто владеет активным координативным (полное соблюдение норм обоих языков) двуязычием, относятся обычно представители так называемой гуманитарной интеллигенции (преподаватели, научные работники, журналисты), обучавшиеся в школе, а иногда и в ВУЗе, бурятскому языку. И если раньше у бурят преимущественно отмечалось активное контактное двуязычие, которое развивалось у городских бурят при непосредственном общении с представителями других национальностей, то в последние десятилетия можно говорить еще и о массовом пассивном культурном двуязычии, которое распространяется в отдельных сельских районах через радио, телевидение и другие средства массовой информации. Наблюдающийся значительный перевес числа носителей русского языка даже среди бурят имеет тенденцию к усилению этого перекоса. Часто причинами предпочтения русского языка бурятскому являются степень владения тем или иным языком и стереотип языкового поведения.

Таким образом, в настоящее время можно говорить практически о четырех видах двуязычия на базе бурятского и русского языков: 1) бурятско-русское двуязычие у бурят, 2) русско-бурятское двуязычие у бурят, 3) бурятско-русское двуязычие у русских, 4) русско-бурятское двуязычие у русских. Если первый вид двуязычия достаточно изучен, имеются различные, в том числе и статистические, данные по этому виду, то остальные три требуют не только исследования, но и внимательного отношения, поскольку от них во многом зависят и будущее положение бурятского языка в Бурятии, и моральный климат в республике. Обычно бурятский компонент бурятско-русского двуязычия у бурят представляет собой диалект или говор, но в случае, если носитель языка обучался в школе родному языку, в его речи наблюдается явление диглоссии, перемежаются литературная и диалектная фрормы бурятского языка, а также элементы русского.

По данным, полученным в результате проведенного в 1989-1990 гг. обследования, по уровню владения бурятами бурятским и русским языками активными носителями бурятско-русского двуязычия являются более $60 \%$ взрослого населения, носителями русско-бурятского двуязычия среди них являются примерно 23\% (ответивших, что удовлетворительно и плохо говорят по-бурятски) опрошенного взрослого населения этнографической Бурятии. Расчет по ре- 
зультатам переписи населения 1989 г., данный в работе Хо Сун Чхол (Хо Сун Чхол 2000: 386), показал, что степень двуязычия у бурят равняется $74,45 \%$.

Бурятско-русское и русско-бурятское двуязычие у русских представлено редко и, в основном, у лиц, живущих в сельской местности, в окружении природных одноязычных носителей бурятского языка. По данным переписи населения 1989 г., 0,3\% русских ответили, что знают бурятский язык, однако имеются сведения, что в сельской местности около $40 \%$ русскоязычного населения в той или иной степени владеют бурятским языком, а в городе доля носителей русско-бурятского двуязычия составляет $27 \%$ (Проблема двуязычия 1998).

Бурятский язык входит в группу монгольских языков. В настоящее время бурятский языковой ландшафт характеризуется наличием достаточно развитого литературного бурятского языка, в основе которого лежат диалект хоринских бурят, старомонгольский язык, бурятский фольклор, а также ряда диалектов и говоров, которые, в основном, функционируют в бытовой сфере, и разговорного языка, занимающего промежуточное положение между бурятским литературным языком, диалектами и русским языком.

Пока слабо определившимися и соответственно изученными являются разговорное просторечие, социолекты, жаргоны. Нет единого мнения относительно бурятских диалектов, даже их число варьирует у разных авторов. Так, Т.А. Бертагаев (Бертагаев 1968: 32) выделяет четыре диалекта: западный, восточный, южный и нижнеудинский; и 11 говоров, которые, в свою очередь, распадаются на подговоры. А.А. Дарбеева (Дарбеева 1997) считает, что бурятский язык подразделяется на три диалекта: западный, восточный и южный, 14 говоров и семь подговоров. И.Д. Бураев, Л.Д. Шагдаров (Бураев, Шагдаров 1995) делят бурятский язык на четыре диалектные группы: хоринскую, цонголосартульс-кую, эхирит-булагатскую и аларо-тункинскую. Выделение данных групп, считают авторы, отчасти связано с этническим делением носителей языка, хотя и не совсем: североселенгинские буряты генетически относятся к эхиритам, а по языку - более к хоринскому диалекту.

Что касается истории развития бурятского языка, то большинство лингвистов-бурятоведов отмечают, что до Октябрьской революции бурятский язык функционировал в основном в виде диалектно-разговорной формы, что объяснялось уровнем его исторического развития, неграмотностью основной массы бурят. В культурной сфере преимущественно использовались бурятский и тибетский языки. Бурятский язык функционировал в виде устной культурной разновидности, а языком богослужения был тибетский (начиная с XVII в., периода проникновения буддизма на территорию современной Бурятии). Литература для богослужения лам была в письменной форме на тибетском языке. Бурятский язык был также вспомогательным при обслуживании низшего уровня культового общения (шаманизм).

Низкий уровень образования, с одной стороны, способствовал консервации, сохранению бурятского языка, поскольку его носители не изучали и не знали ни русского, ни тем более какого-либо иностранного языка; но он и не способствовал его развитию, изучению, выработке каких-либо литературных норм. В частности, это одна из причин, почему до революции не была решена и проблема реформы старомонгольского письма, которой пользовалось грамотное бурятское население.

Хочется также отметить, что исторически было естественно, когда в определенный период большинство лингвистов-бурятоведов утверждали вслед за ведущими советскими языковедами, что бурятский язык является младописьменным (Шагдаров 1984), и как большинство малочисленных народов СССР буряты обрели свою письменность в советское время. Однако существовали и 
существуют другие мнения, и сегодня большинство специалистов согласны с утверждением Ц.Б. Цыдендамбаева (Цыдендамбаев 1958) о том, что до революции бурятский язык не был бесписьменным. Да, они пользовались общей с монголами письменностью, но при этом, например, тексты бурятских исторических хроник и родословных имеют уже свои специфические особенности.

Образование в 1923 г. Бурят-Монгольской АССР ознаменовало новый этап в становлении бурятской нации. Были созданы условия для национальногосударственного строительства, консолидации бурят, ликвидации неграмотности. В «Положении о государственном устройстве Бурят-Монгольской Автономной Советской Социалистической Республики», утвержденном ВЦИК 12 сентября 1923 г., бурят-монгольский и русский языки были объявлены равноправными ${ }^{4}$, что сегодня некоторыми исследователями воспринимается, как утверждение национальных языков в качестве государственных (Мартин 2002: 56), хотя общеизвестно, что большевики были против того, чтобы какой-либо язык объявлять государственным.

В русле новой национально-языковой политики советского руководства, проводимой особенно активно относительно окраинных языков, практически, все они первоначально были ориентированы на генетически и типологически родственные более крупные языки, и соответствующую письменность. В бурятском языке в эти годы успешно развивались традиции старомонгольского письменного языка, начал создаваться во многом общий с халха-монголами литературный язык на базе восточных говоров. И здесь мы сталкиваемся с одной из наиболее сложных проблем бурятоведения, проблемой бурятского литературного языка.

Как отмечают сегодня многие языковеды национальных республик, истинная картина истории развития национальных языков и их фрорм требует некоторого уточнения. Общеизвестно, что для становления литературного языка очень важно наличие письменности. Многие же из так называемых младописьменных языков имели письменные источники и памятники, для языка которых характерны признаки литературного языка. Не является исключением и бурятский язык. По мнению Л.Д. Шагдарова, становление бурятского литературного языка началось в 1920-е гг. на основе еще старомонгольской письменности, что подтверждает анализ литературы, изданной в те годы. Именно в художественной литературе заметно вытеснение старомонгольских элементов элементами народно-разговорного языка (Шагдаров 1993).

Так же, как и во многих других языках, проблема графического оформления, тесно связанная с культурно-религиозной, а иногда и политической ориентацией носителей языка, в бурятском языкознании обсуждалась не один десяток лет. Вопросы письменности всегда принадлежали к наиболее сложным и больным вопросам прошлого бурят. Видный бурятский ученый и национальный идеолог того времени Базар Барадин считал, что главный недостаток старой письменности в том, что она тормозила развитие и распространение просвещения. Однако в тридцатые годы основной причиной смены алфавита посчитали классовую сущность старой письменности, письменности лам и нойонов. Латинизация бурятского алфравита (1931 г.) так же, как и любое мероприятие такого масштаба тех лет, сопровождалась обширной дискуссией и критикой, в основном политического характера.

Однако уже в 1934 г. стало очевидно, что новый алфавит в Бурятии не привился, о чем свидетельствовали, например, такие показатели: в 1929-1930 гг. газета «Унэн» печаталась на старом алфравите тиражом 10000 экз., а в 1931

${ }^{4}$ НАРБ, Ф. Р-2, оп. 1, д. 43, л. 69-70 (к). 
г., после введения нового алфавита, тираж упал до 5160, в 1933 - до 1350 экз. ${ }^{5}$ Причиной неудачи посчитали то, что в латинской графике не хватало букв для обозначения специфических фонетических явлений бурятского языка, для чего были введены искусственные буквы, правила орфографии были неполными. Кроме того, ошибкой считалось то, что за основу нового бурятского языка был взят сначала халха-монгольский язык, а затем селенгинский говор, а не живой разговорный язык всех «трудящихся масс». Но фрактически главная причина была в излишней идеологизации проводимых мероприятий, объявлении языка орудием классовой борьбы, внедрении нового алфавита "сверху» насильственными методами, без объяснения, убеждения в его преимуществах.

В сентябре того же 1931 г. состоялся Объединенный пленум ОК и ОКК ВКП(б), на котором в развитие решений ЦК был сформулирован курс на строительство социалистической по содержанию и национальной по форме культуры бурятского народа. Перед институтом культуры (бывшим Буручкомом) ставилась задача выработки нового литературного языка на основе одного из бурятских наречий. Выполняя это решение, в 1931 г. бурятский язык был переведен на латинский алфавит, а за основу литературного языка было взято селенгинское наречие. Однако и эта реформа, считалось, не дала положительного эффректа, и в результате многолетних и жарких дискуссий в 1936 г. было принято решение ориентироваться на восточнобурятское h-акающее наречие.

Сегодня можно утверждать, что, несмотря на наличие достаточно большого числа вопросов и проблем бурятского языкознания, уровень нормированности литературного бурятского языка относительно высок: последний свод правил орфографии утвержден в 2009 г., в 1962 г. издана академическая грамматика бурятского языка, имеются переводные и орфогра-фрический словари, а также разнообразные учебные пособия и грамматики, готовится к изданию толковый словарь бурятского языка. Для литературного бурятского языка характерно стилистическое многообразие, обычно в нем выделяются художественно-литературный, общественно-публицистический, учебнопедагогический, литературно-разговорный стили, для него характерно наличие лексико-орфоэпических норм. Не получили должного развития официальноделовой и научный стили. Редкое исключение составляют публи-кации научнопопулярных работ гуманитарного профиля, учебная литература, перевод и издание законов и постановлений Народного Хурала и прави-тельства РБ, защита диссертационных работ по филлологии.

Особенностью современной национально-языковой ситуации в республике является то, что впервые в истории бурятского народа бурятский язык приобрел юридический статус. Основными государственными документами по юридическому статусу бурятского языка являются Конституция Республики Бурятия (статья 67), принятая 22 февраля 1994 г., и закон «О языках народов Республики Бурятия» (статья 1), принятый 10 июня 1992 г., согласно которым русский и бурятский языки были признаны государственными языками.

Принятый закон направлен на укрепление позиций бурятского языка, он предусматривает кардинальное расширение функционирования государственного бурятского языка во всех сфрерах, поддающихся правовому регулированию, особое внимание, как и в большинстве республиканских языковых законов, уделено области образования, поскольку оно должно обеспечить преемствен-ность поколений, воспитание у молодежи любви и уважения к собственной культуре и языку, языку и традициям других народов. С помощью образования создаются

${ }^{5}$ НАРБ, Ф. 1, оп. 1, д. 2268, 1934 г., л. 28. 
предпосылки более активного фрормирования русско-бурятского двуя-зычия, пока малораспространенного в республике.

В целях реализации закона «О языках народов Республики Бурятия» Правительством РБ в 1996 г. было принято постановление № 241, в котором отмечалось, что ряд статей закона в полном объеме не выполняются, была разработана и одобрена Советом Министров РБ Государственная программа сохранения и развития языков народов Республики Бурятия, но которая не была утверждена Верховным Советом РБ и, соответственно, осталась без фринансирования. Основной упор в данной программе делался на решение учебнообразовательных и организационно-методических задач. Небольшие разделы по редакционно-издательской деятельности и развитию языка в сфере государственного управления, фрактически, не предлагали ничего нового. Так же, как и многие постановления того периода, оно не было исполнено в большей части из-за отсутствия финансирования. Не была также создана комиссия по языкам при Правительстве Бурятии. Все свелось к созданию в 1998 году государственной службы языкового перевода правительственных документов, состоящей из четырех человек, в функции которой в основном входит перевод законодательных документов РБ.

Реализация закона в период до 2010 г. осуществлялось посредством принятия Постановлений Правительства РБ, которые, в том числе, включали и языковую проблему. Так, Постановлением № 336 от 29.09.1997 была принята Концепция государственной национальной политики РБ, согласно которой языки коренных национальных меньшинств включались в программы учебных заведений в районах их компактного проживания. Среди целей и задач государственной национальной политики указывалось воссоздание и совершенствование национальной общеобразовательной школы как инструмента сохранения и развития национальной культуры и языка. В Программе социальноэкономического развития Республики Бурятия на 2002-2004 годы (Постановление № 187 от 23.05.2001), предусматривалось выделение средств в рамках Программы сохранения и развития языков народов республики на издание учебников национально-регионального компонента, а также на сохранение контингента учащихся, изучающих бурятский язык. Примерно на эти же цели были направлены средства, предусмотренные в Республиканской целевой программе «Развитие образования и науки в Республике Бурятия на 2004-2007 годы» (Постановление № 296 от 22.09.2003). Таким образом, можно сказать, что в течение многих лет государственная программа по сохранению и развитию бурятского языка напрямую не финансировалась.

В 2006 г. при Правительстве РБ была создана комиссия по развитию бурятского языка, которую возглавляет Первый заместитель председателя Правительства республики. В дальнейшем в целях реализации закона была принята Концепция развития бурятского языка, принятая Постановлением Правительства РБ № 80 от 12 марта 2009 г. Постановлением Правительства РБ от 2 августа 2010 г. № 312 принята Государственная программа Республики Бурятия «Сохранение и развитие бурятского языка на 2011-2014 гг.», инфрормация о ходе выполнения которой ежегодно заслушивалась на заседании комиссии. В настоящее время действует программа на 2014-2020 гг. с объемом финансирования в среднем 30 млн руб. в год.

Среди положительных моментов улучшения положения бурятского языка после принятия Закона можно отметить, в основном, те, которые были реализованы в области образования Министерством образования и науки РБ. В настоящее время ответственность за исполнение языкового законодательства 
возложена на Комитет Народного Хурала РБ по межрегиональным связям, национальным вопросам, молодежной политике, общественным и религиозным объединениям, исполнение Государственной программы проводится при поддержке Министерства образования и науки и Министерства культура РБ.

Из трех 6 основных сфер использования бурятского литературного языка, регламентируемых государством и поддающихся законодательному регулированию (народное образование, духовная культура, массовая коммуникация), только в одной - народном образовании - более или менее планомерно ведется работа по внедрению закона «О языках народов Республики Бурятия».

В связи с принятием языкового законодательства изменения были внесены на всех ступенях национального образования, обновлены программы обучения в дошкольных и школьных учреждениях, средних школах, касающиеся обучения бурятскому языку. Появились бурятская школа-интернат, бурятский лицей, аграрный национальный колледж, национальные гимназии, лицей для одаренных детей. Наряду с ними, в республике функционируют классическая русская гимназия. Изучение бурятского языка вводится во многих обычных школах, в ПТУ в виде кружков, курсов, фракультативов.

В 2002 г. бурятский язык изучался в более чем в 300 школ из 588 (примерно 60\%), в одной четвертой части дошкольных образовательных учреждений (более 100), в 25 из 37 учреждений начального профессионального образования, в четырех средних специальных учебных заведениях, Бурятском государственном университете и Восточно-Сибирской государственной академии культуры и искусств. Положительная тенденция наблюдалась и в изучении языков народов Севера (эвенкийский и сойотский с 2002 года). В 30 школах преподается старомонгольская письменность.

В настоящее время 80\% школ Бурятии ввели или вводят изучение бурятского языка независимо от национального состава контингента учащихся. На 2011-2012 уч. г. в 118 школах бурятский язык преподавался как родной (264 учителя и 8596 учащихся): 4-5 часов в неделю с 1 по 9 класс. В 218 (475 учителя и 60120 учащихся) школах преподавания идет по программе «бурятский язык как государственный»: два часа в неделю. В школах введен региональный стандарт и региональный базисный план, введена единая форма экзамена по бурятскому языку: традиционная (для бурятских школ) и в фрорме тестирования (для русских школ). Однако, как свидетельствуют данные социологов, по системе образования только $38 \%$ школьников и $29 \%$ дошкольников владеют бурятским языком.

Произошли некоторые изменения и в сфере высшего образования ${ }^{7}$ (всего в Бурятии четыре вуза): в 1991 г. в Бурятском государственном университете был открыт специальный фракультет бурятской фрилологии, ныне Национальногуманитарный институт важнейшей задачей которого является развитие и распространение бурятского языка, подготовка научных и педагогических кадров в области бурятской фрилологии. Позднее на фракультете было открыто отделение журналистики. Кроме бурятского фракультета, язык изучается на нацио-

\footnotetext{
${ }^{6}$ Как отмечают авторы энциклопедии «Письменные языки мира» [2000, X1], существует прямая зависимость между количеством социальных функций языка и его жизненностью, которая измеряется объемом его основных функций, его применением в наиболее важных сферах жизни общества: образовании, науке, массовой коммуникации, суде, производстве, административной деятельности, промышленности, социальнополитической сфере, религии.

${ }^{7}$ На сегодня в Бурятии четыре государственных вуза. Всего около 20000 студентов, около 2000 - профессорско-преподавательский состав. При Иволгинском дацане действует высшее учебное заведение - Буддийский институт «Даши Чойнхорлин». Доля коммерческих вузов небольшая, всего один вуз, восемь - филиалы центральных учебных заведений.
} 
нальном отделении факультета начального обучения БГУ, где готовят учителей начальных классов. В Восточно-Сибирской государственной академии культуры и искусств бурятский язык преподается на четырех фракультетах. Кафедра бурятского языка имеется в Иркутском государственном университете и Забайкальском государственном педагогическом университете (г. Чита). Расширились возможности использования национально-регионального компонента не только в школьной, но и вузовской системе. Например, в БГУ создана кафредра истории и культуры Бурятии. Апробированы и введены в виде курсов и предметов: История Бурятии, Краеведение, Национальное прикладное искусство, Философия буддизма, Литература Бурятии, Старомонгольское письмо, История мировых религий, Этнография, Этнопедагогика и др.

Основными направлениями в области образования согласно Госпрограмме по реализации Закона на 2010-2013 гг. являются учебно-методическое обеспечение в сфере образования и обучения бурятскому языку, научное обеспечение сохранения и развития бурятского языка и использование информационных технологий для его развития. В частности, поставлена задача доведения обеспечения необходимой учебной литературой до $60 \%$.

Что касается функционирования языка в сфрере высшего образования, то можно отметить, что в преподавательской среде часто можно слышать бурятскую речь, но, практически, кроме бурятского фракультета Бурятского госуниверситета нигде лекции на бурятском языке не читаются. В целом для речевой научной культуры бурят не характерно использование родного языка. Можно насчитать единичные случаи, когда научный работник или преподаватель высшей школы мог полностью выступить или прочитать лекцию по специальности на родном языке. Отдельные попытки по разработке научной тематики наблюдаются в последние годы среди гуманитариев-филологов, пишутся диссертационные исследования по бурятской литературе, фольклору, языку. Как отмечают авторы, основные трудности связаны с отсутствием и неразработанностью терминологии и в трудных случаях приходится прибегать к заимствованиям из русского или монгольского языков.

Пока проблемными остаются следующие вопросы системы образования на бурятском языке и обучения бурятскому языку: дисперсное расселение не способствует полному охвату обучением всех детей бурятской национальности; относительно слабое кадровое (старение педагогических кадров и текучесть кадров из сельских школ) и материальное обеспечение обусловливает низкое качество преподавания бурятского языка особенно в сельских школах, которые преимущественно являются национальными; языковой нигилизм отдельных учащихся и их родителей в городских и пригородных школах. В среднем, не хватает 300 учителей бурятского языка. В трех районах (Кабанский, Бичурский, Тарбагатайский) бурятский язык не изучается.

Отдельные национальные школы, особенно в городе, являются достаточно престижными, качество преподавания в них, разнообразная программа подготовки иногда прельщает учащихся, однако у республики нет возможностей обеспечить высококвалифицированными кадрами и другими материальными ресурсами все школы, хотя очевидно, что национальная школа по качеству обучения должна быть лучше, чем обыкновенная школа.

В Бурятии функционирование бурятского языка поддерживается и по возможности развивается республиканскими средствами массовой информации.

Проведенное в конце 1980-х гг. обследование показало, что информационное обслуживание на бурятском языке очень незначительно, лишь около $20 \%$ бурятского населения регулярно слушало радио, смотрело телепередачи, читало периодику на бурятском языке. В результате анализа 
данных 1998 г. по селам Бурятии было отмечено, что ситуация резко ухудшилась. Газеты и журналы в селах выписывали и выписывают сейчас немногие, всю внешнюю инфрормацию люди получают преимущественно посредством телевидения. При опросе некоторые сельчане отмечали необходимость создания отдельного национального канала.

В 2005 г. доля вещания на бурятском языке на местном телевидении составляла $1 / 4$ часть, местного радио - $1 / 3$ и 1/18 общего государственного вещания. Сегодня она увеличилась до $40 \%$ на канале ГТРК «Бурятия» и, как было отмечено на Круглом столе Всероссийского фестиваля национального вещания «Байкальская волна» (август 2012 г.), 90\% населения республики сегодня могут смотреть данные передачи. Незначительно, но увеличился объем вещания на бурятском языке и на других местных каналах - Ариг Ус, Тивиком. Появились коммерческие каналы АТВ и «Селенга», которые также много внимания уделяют передачам на бурятском языке. Однако в общей массе центрального и местного вещания этот объем составляет примерно один процент, что, очевидно, не соответствует доле бурятской теле- и радиоаудитории. Кроме того, можно отметить, что начавшееся в 2016 г. вещание на канале Буряад радио FM ведется при поддержке Буддийской Сангхи России на пяти бурятских диалектах.

Из 208 периодических печатных изданий только восемь выходят на бурятском языке. Кроме старейшей республиканской газеты «Бурят Унэн», выходят общественно-политические и литературно-художественные журналы «Байгал» и «Моринхуур», детский журнал «Одон» на трех языках - бурятском, русском и английском, иногда еще на эвенкийском языках. Из числа районных газет на бурятском языке сохранились и издаются лишь четыре (в Закаменском, Еравнинском, Кижингинском, Тункинском районах). Из них лишь одна «Хэжэнгэ» выходит раз в неделю, остальные - раз в месяц. Их тиражи колеблются от 100 до 500 экземпляров. В основном в эти годы небольшие брошюрки стихов и прозы издавались районными типографиями за счет средств спонсоров и самих авторов.

Законодательное закрепление бурятского языка в качестве государственного способствовало тому, что его реализация с помощью Государственной Программы получило финнансовую поддержку Правительства республики. Однако относительно СМИ в ней говорится пока только о поддержке проекта радио FM и медиа-плане по использованию эфирного времени в действующих телерадиоканалах.

Решение проблем любого национального языка тесно связано с вопросами развития национальной культуры: литературы, искусства, народного творчества, системы обрядов и традиций т.д.

Литература является одним из наиболее универсальных видов духовной культуры, участвующих в формировании национального самосознания, важнейшим компонентом неформального общения и мощнейшим стимулом поддержки языковой традиции. Современные проблемы национальных литератур связаны как с проблемами культурной интерференции, взаимопроникновением культур, так и с активной компьютеризации, освоением Интернета. Для бурятской литературы все это вылилось в жесточайший кризис, наблюдаемый в настоящее время. Об этом, в частности, можно судить по количеству изданий: в 1985-1995 гг. наблюдался резкий спад литературного процесса, всего в этот период было издано пять романов. В 1995 г. Бурятским книжным издательством было выпущено семь книг и брошюр на бурятском языке ${ }^{8}$. В

\footnotetext{
${ }^{8}$ По архивным данным с 1970 по 1974 гг., например, на бурятском языке было издано 655 наименований, в том числе 100 - партийно-идеологическая, 68 - художественная проза, 69 - поэзия, 135 - детская литерату-
} 
1998-1999 годах бурятским книжным издательством издано всего 8 книг (все на русском языке), в 2000 г. - 20, из которых только две на бурятском языке и одна - на эвенкийском и русском языках. Опубликованный тиражом 1000 экз. роман «Тоонто нютаг» реализуется с большим трудом. Практически, не издаются детские книжки, чувствуется недостаток литературы по школьной программе ${ }^{9}$. В период с 2000 по 2005 годы вышли всего две небольшие книжки на бурятском языке. Всего за последние 10 лет вышло в свет 3011 книг, из них на бурятском языке - 148 (5\%), причем большинство изданий имеют тираж 100-500 экз. Практически, язык оказался вытесненным из важнейшей вербальной сфреры бурятской культуры.

Причиной такого положения является не только увеличение цен, диктат издательств, общий экономический спад, а также то, что в результате новых социальных установок изменивших идеологическую направленность, на книжный рынок хлынула разнообразная, часто низкопробная литература. Главное - сокращение количества писателей, пишущих на бурятском языке, сложная языковая и личностная трансформация, которая длится уже не одно десятилетие. И если в первые десятилетия «культурной революции» ввиду неразвитости бурятско-русского двуязычия основную массу составляли переводы и, фрактически, происходило дублирование издания всей литературы на русском и бурятском языках, то во второй половине $\mathrm{XX}$ века произошло объективное сокращение подобных изданий, те, кто знал русский язык, предпочитали читать литературу в подлиннике. Постепенно произошло функционально-стилистическое разграничение изданий, и при этом очевидной стала несоотносительность объемов и характера публикаций на бурятском и русском языках.

Соответственно, несмотря на то, что свободно читать на бурятском языке могут $64 \%$ взрослых и 90\% школьников ${ }^{10}$, по данным социологического опроса 1995 г. (Рандалов 2002: 34), только 11\% опрошенных ответили, что «читают художественные произведения бурятских писателей, сказки, былины, эпос бурятского народа» на родном языке, $43,1 \%$ ответили, что читают их в переводе на русский язык, 29,4\% - на обоих языках. Или можно сказать, что владение языком не влияет на приобщенность к бурятской литературе. Соответственно, только у $10 \%$ семей имеются небольшие библиотеки с книгами на бурятском языке, $44 \%$ ответили, что имеют небольшой набор книг на родном языке, а у $45 \%$ семей дома кроме учебников бурятского языка других книг на родном языке не имеется. Очевидно, что причина здесь не только в том, что буряты отлично владеют русским языком и не нуждаются больше в родной литературе. Фактически, ее зачастую просто нет и даже в библиотеках в случае запроса, например, детской литературы на бурятском языке, указывают на маленькую стопку книг где-то на нижней полке в конце зала.

Несмотря на все эти трудности, имеются обнадеживающие симптомы. В 2001 г. учреждено государственное издательство «Бэлиг» как вспомогательное

ра, 65 - учебные пособия, 40 - научно-популярная, краеведческая. Переводилась вся идеологическая литература, художественная классическая литература.

${ }_{9}^{9}$ Как считает Е.Н. Грошева [Книгоиздание на бурятском языке на современном этапе: реальность, ожидания и поиски развития // Бурятский язык и культура в условиях глобализации. Мат-лы науч.-практ. конф. (11-12 ноября 2005 г.). Улан-Удэ: Изд-во Бэлиг, 2005. С. 187-189], скорее, можно говорить об отсутствии книжного рынка на бурятском языке, чем о его наличии.

${ }_{10}$ Данные Е.Н. Грошевой, опубликованные в статье: Состояние книгоиздания на бурятском языке глазами читателей Республик Бурятия // Библиотечное дело: традиции, новые технологии и формы сотрудничества. Мат-лы регион. научно-практ. конф., посвящ. 75-летию со дня рожд. Ю.А. Хараева (29 мая 2003 г.) / Мин-во культуры РБ. Нац. библиотека РБ, ВСГАКИ. Сост. И.И. Петухова, Л.Н. Дарьенко. Улан-Удэ, 2003. С. 49-55. 
предприятие министерства образования и науки РБ по изданию учебной, научно-методической и художественной литературы на бурятском языке.

Что касается области театрального и киноискусства, то можно лишь отметить наиболее сильный и авторитетный коллектив Бурятского академического театра драмы, который формирует и поддерживает высокий уровень устного сценического искусства Бурятии благодаря высокой квалификации актеров и достаточно богатой, разнообразной драматургической литературе на бурятском языке. Производства кинофильмов на бурятском языке не существовало, и в настоящее время единичны случаи использования бурятского языка в этом жанре. В последние годы наблюдаются попытки возрождения различных самодеятельных коллективов, выступающих на бурятском языке, но из-за общего экономического кризиса, особенно сказавшегося на культуре, их немного.

Существенную поддержку языку оказывают знания национальных традиций и обычаев. В последние годы наблюдается активизация малых жанров бурятского фрольклора: песни, благопожелания, топонимические легенды, рассказы, генеалогические предания, присказки и т.д. При этом происходит естественная их трансформация в новых социальных условиях, переосмысление старых фрорм, поиск новых. Так, к наиболее развивающимся относятся магтаалы (прославления) и юроолы (благопожелания). При этом необходимо отметить, что при сохранении и даже дальнейшем развитии фрормы происходит разрушение фрункциональной значимости. Этому способст-вуют различного рода мероприятия: конкурсы, соревнования, празднества, турниры и т.д. Необходимость придания тому или иному мероприятию нацио-нального колорита подчас приводит к несоблюдению, нарушению традицион-ного ритуала, что обычно является следствием незнания либо стремления к их стилизации.

Как показывают опросы, одним из основных элементов бурятской культурной идентичности наряду с юроолами и магтаалами сегодня является песня, они служат и маркерами культурной специфики и свидетельством бурятского культурного единства. Среди населения республики очень популярно бурятское песенное искусство, причем отдельные песни знают и местные русские жители. Активизация данного жанра объясняется несколькими факторами. В первую очередь, богатыми вокальными данными бурят, далее, наличием прекрасной поэзии и, несомненно, талантливыми композиторами. Проведение регулярных песенных конкурсов как местного, так и международного значения также во многом способствует развитию этого жанра. Имеется достаточное количество магнитофонных записей как современных, так и народных бурятских песен.

Популярными остаются легенды, предания, улигеры, устные рассказы. Вершиной бурятской поэзии считаются улигеры - монументальные эпические поэмы героического содержания, в которых реальные исторические события представлялись ярко, точно и красочно, обильно сопровождались описанием жизненных наблюдений, рассуждений и обобщений. Всего в сокровищницу художественного наследия бурят включено более сотни таких улигеров. Сказители или улигершины были одними из самых почитаемых людей, слава о них обычно распространялась далеко за пределами того или иного улуса. Состязания улигершинов, нередкие в прошлом, были возрождены в последние десятилетия. Интерес к таким видам фрольклора как улигеры во многом был обусловлен интересом к своему прошлому, поиску себя в новой жизни.

В связи с утратой элементов традиционного хозяйства постепенно забываются и охотничьи и промысловые заклинания. 
К сожалению, все менее распространенными становятся или не развиваются такие детские жанры как колыбельная, сказки и загадки, чему во многом способствуют отсутствие ярких современных детских изданий на бурятском языке, вытеснение бурятской сказки русской, телевизионная реклама и мультфильмы, а в последние годы и компьютерные игры.

Доминирующим в социально-коммуникативной системе, особенно в официальной, является русский язык, который обслуживает весь спектр общественных ссрер. В республиканских органах законодательной и исполнительной власти бурятский язык фрактически не используется, хотя при Правительстве РБ в 1998 году была создана государственная служба языкового перевода правительственных документов, состоящая из четырех человек, в функции которой, в основном, входит перевод законодательных документов РБ.

Bсе законы, постановления и указы пишутся и принимаются на русском языке. Лишь отдельные законы Народного Хурала (Парламента) РБ и некоторые указы в переводе на бурятский язык дублируются в газете «Бурят Унэн». Вся документация, делопроизводство, официальная переписка даже с районными администрациями, в которых преобладает бурятское население, ведутся на русском языке. Это подтверждается и результатами обследования: в сельской местности все чаще на производстве используется русский язык. Только отдельные руководители бурятской национальности могут беседовать с собеседниками-бурятами на бурятском языке. В последние годы после принятия закона стало практиковаться открывать конференции, симпозиумы, крупные совещания на бурятском языке.

Бурятский язык практически не функционирует в судопроизводстве, промышленности, сферах обслуживания, торговли, транспорте, связи. В научно-преподавательской деятельности, сферах естественных и технических наук также господствует русский язык. В гуманитарных науках бурятский язык представлен в отдельных работах, имеется, как отмечено выше, несколько кандидатских диссертаций, написанных на бурятском языке. В сорере сельского производства бурятский язык используется чаще в устном общении, иногда - в выступлениях в однородной бурятоязычной аудитории. Несмотря на то, что в законе «О языках народов Республики Бурятия», принятом в 1992 г., указано, что все объявления, вывески, знаки маркировки продукции и т.д. должны быть офрормлены на двух государственных языках, данный пункт, практически, не выполняется. В муниципальном транспорте - в отдельных видах трамвая, имеющих техническое обеспечение - в 2013 г. введено автоматическое объявление остановок на бурятском языке.

Бурятия находится не только на пересечении различных культур, но и религий. Традиционными на данной территории являются буддизм, христианство и шаманизм. В последние годы в связи с возвратом многих забытых национально-культурных и религиозных ценностей, традиционной народной медицины несколько усилились и позиции бурятского языка. Возрождение народных праздников и обрядов, открытие дацанов, национально-культурных центров, землячеств способствовало не только тому, что буряты стали вспоминать давно забытые слова, но и переоценке значения родного бурятского языка. Вероятно, для большей доступности религиозных обрядов и служб в некоторых дацанах с 2001 г. предпринимаются попытки совершать их не только на традиционном тибетском, но и на бурятском языке либо старомонгольском. И если для буддизма более характерны такие фрормы как магтаалы, то для шаманизма - призывания. Рост практикующих шаманов вызвал активизацию обучения шаманским призываниям. 
Активизация данной сферы общения позволила, в частности, Э.В. Хилхановой (2007) выделить ее как самостоятельную макроситуацию. По ее данным 41,7 \% молодых людей используют в данном случае родной язык (ср. в официальной сфере - 7,4 \%). Причем в Бурятии данный показатель является самым высоким среди всех сорер общения по всем группам населения. Это позволяет автору утверждать, что бурятский язык остается конкурентоспособным в семейно-бытовой сфере и доминирующим в религиозной.

В сфере бытового общения буряты пока преимущественно используют родной язык, однако для городского населения все более характерным становится использование русского языка даже в быту. Число лиц, пользующихся только бурятским языком, небольшое, в основном, это дети дошкольного возраста и женщины преклонного возраста, живущие в отдаленных улусах. По данным социолингвистической энциклопедии «Письменные языки мира» (2000), число бурятских монолингвов составляло в России 58738 человек (14 \% всего бурятского населения), в Республике Бурятия - 39209 человек (15,7 \%). Как и у других народов, основная часть носителей владеет диалектной и просторечными фоормами языка. В сельских районах РБ и округах бурятскорусское двуязычие носит диглоссный характер, с достаточно широкой областью равного употребления бурятского и русского языков.

Поскольку представители русской национальности в основном моноязычны, подавляющее большинство лиц различных этнических групп русскоязычны во всех ситуациях общения, а уровень владения бурятами русским языком достаточно высокий, в официальной сфрере - на работе, в общественных местах, в учебных заведениях, при чтении и восприятии информации посредством СМИ, на транспорте - используется, в основном, русский язык. Уровень функциональной нагрузки бурятского языка в официальной сфрере намного ниже, чем русского, что объясняется также рядом объективных фракторов: спецификой официальной сферы, обычно многонациональным составом коллектива, невысокой долей владеющих литературной фрормой бурятского языка. Как считают многие бурятские лингвисты, функциональная дистрибуция русского и бурятского языков в республике обусловлена социально-демографическими фракторами, а также формами их существования.

Таким образом, соотношение бурятский/русский язык характеризуется тем, что они имеют одинаковый юридический статус, но функциональные возможности бурятского языка значительно ниже и достаточно не развиваются. Бурятско-русское двуязычие в основном характеризуется функциональным распределением языков, когда русский язык соотносится с нетрадиционными для бурят сорерами деятельности, а родной используется в повседневно-бытовом общении. При этом в городе основной сферой общения на бурятском языке является семья, родственники, однако и здесь все чаще переходят на русский язык. Для сельских районов республики, где преимущественно проживает бурятское население, характерно широкое распространение бурятско-русского двуязычия. В официально-социальной среде здесь чаще, чем в городе используется бурятский язык. В быту, с друзьями и родственниками обычно общаются по-бурятски. Однако при переписке, чтении книг, в использовании средств массовой информации, при общении в магазинах, транспорте и т.д. все чаще и более широко используется русский язык. Число признавших, что плохо понимают или говорят по-русски, не превышает 1 процента. Как показывают последние опросы, по сфрерам общения в Бурятии наблюдается существенное увеличение билингвов и использование бурятского языка дома, что связано, скорее всего, с введением школьного обучения бурятскому языку. Однако при этом имеется в среднем 5-процентное уменьшение доли предпочитающих общаться 
с друзьями и родственниками только на бурятском языке, в данной сфере чаще стали использовать оба языка. В общественных местах также стали больше использовать и бурятский, и оба языка, сокращается доля использующих родной язык на работе.

Из сказанного выше следует, что в республике доминирующим во всех сфрерах социально-культурной жизни является русский язык, он обслуживает весь спектр общественных функций и обладает самой высокой коммуникативной мощностью. Набор функций, в которых используется второй государственный - бурятский - язык, незначителен. С учетом интенсивности его использования эти сферы можно распределить следующим образом: сфера межличностного повседневного общения, образование, духовная культура, массовая коммуникация, книгопечатание. При этом в данных сферах его использование ограничено однородной бурятоязычной средой. Ограничено или недостаточно он используется в руководящих органах, при судопроизводстве, на производстве, в сфрерах обслуживания, делопроизводстве, торговле, транспорте, связи, науке, рекламе и т.д.

Основными языками-компонентами языковой ситуации в Республике Бурятия являются русский и бурятский языки. В связи с тем, что в республике наблюдается демографическое неравновесие, это отражается и на языковой ситуации: русский язык обладает большей демографической мощностью - 99,7 \% жителей владеют русским языком. Только 13,7 \% населения владеет вторым государственным языком, бурятским (в 2002 г. было 23,6 \%). За последнее десятилетие существенно снизилась доля владеющих родным языком среди самих бурят с 81,4 \% до 43,6 \%.

Коммуникативная мощность бурятского языка также постепенно снижается. Поскольку основная масса бурят и представителей других национальностей, не говоря уже о русских, русскоязычна во всех сферах общения, а образование, социальное продвижение зависят от знания русского языка, количество сфрер использования бурятского языка существенно уменьшилось. Практически, более или менее активно он используется в семейно-бытовой сфере, сфрере художественного творчества, религии, культуре, образовании, сельском хозяйстве, средствах массовой информации, книгопечатании. При этом здесь он обладает неполной взаимодополняющей функцией. Сокращение количества сфрер его использования связано с тем, что он не востребован в таких значимых для общества сферах жизнедеятельности как государственное управление, делопроизводство, промышленность, наука, торговля, сфера обслуживания.

В целом языковую ситуацию в Республике Бурятия можно определить как многокомпонентную, многоязычную, несбалансированную, смешанную эндоэкзоглоссную, неравновесную, в которой русский язык обладает большей демографической и коммуникативной мощностью, чем второй государственный язык - бурятский.

\section{Әдебиеттер тізімі / Список литературы}

1. Бадмаев А.Г. Структурный анализ территориальной дифференциации расселения и хозяйства Республики Бурятия: диссертация на соискание ученой степени кандидата географических наук. - Улан-Удэ, 2011. - С.74-78.

2. Бертагаев Т.А. Бурятский язык // Языки народов СССР. Т.5. Монгольские, тунгусоманьчжурские и палеоазиатские языки. - Л.: Наука, 1968. - С.13-33.

3. Бураев И.Д., Шагдаров Л.Д. Бурятский язык // Государственные языки Российской Федерации. - M.: Academia, 1995. - C.51-59.

4. Верещагин Е.М. Психологическая и методическая характеристика двуязычия (билингвизма). М.: Изд-во Моск. ун-та, 1969. - 160 с. 
5. Дарбеева А.А. Бурятский язык // Языки мира. Монгольские языки, тунгусо-маньчжурские языки, японский язык, корейский язык. - М.: Изд-во «Индрик», 1997. - С.37-51.

6. Итоги Всесоюзной переписи населения 1989 г. Распределение населения по национальности и языку. - Улан-Удэ. - 1990г. - Июнь.

7. Мартин Т. Империя позитивного действия: Советский Союз как высшая форма империализмa? // Ab Imperio. Theory and History of Nationalism and Empire in the Post-Soviet Space. - 2002. N2. - C.55-87.

8. Михальченко В.Ю. Функциональная типология языков России как часть социолингвистической классификации языков мира // Язык как национальное достояние: проблемы сохранения лингвистического разнообразия: Сборник трудов Международной научной конференции. 9-13 сентября 2009 г. - Улан-Удэ: Изд-во БНЦ СО РАН, 2009. - С.34-43.

9. Национальный состав и владение языками; гражданство. - М.: НИЦ «Статистика России», 2004. - 946с. (Итоги Всероссийской переписи населения 2002 г.: в 14 т. - М.: Федеральная служба гос.статистики. - Т.4. - Кн.1).

10. Национальный состав и владение языками, гражданство. Итоги Всероссийской переписи населения 2010 г.: в 11 томах. - Т.4 в 3 книгах. - М.: Статистика России, 2012.

11. Письменные языки мира. Языки Российской Федерации. Социолингвистическая энциклопедия. - Кн.1. - М., 2000. -656 с.

12. Проблема двуязычия в свете общественного мнения // Правда Бурятии. - 1998. - 27 мая.

13. Рандалов Ю.Б. Научное социологическое исследование по проблеме Комплексной программы «Возрождение и развитие национального языка, национальной культуры, традиций и обычаев бурятского народа». - Улан-Удэ: «Буряад унэн», 2002.

14. Хилханова Э.В. Факторы коллективного выбора языка и этнокультурная идентичность у современных бурят (дискурс-аналитический подход). Докт. диссерт. Рукопись. - Улан-Удэ, 2007.

15. Хо Сун Чхол Языковая ситуация в России и других новых независимых государствах бывшего СССР // Языки Российской Федерации и нового зарубежья: статус и функции. - М.: Эдиториал УРСС, 2000. - С.381-391.

16. Цыдендамбаев Ц.Б. За дальнейшее развитие бурят-монгольского литературного языка // Сборник трудов по филологии. - Вып.3. - Улан-Удэ, 1958. - С.3-11.

17. Шагдаров Л.Д. Развитие бурятского литературного языка в условиях двуязычия // Методологические и фиилософские проблемы языкознания и литературоведения. - Новосибирск: Наука, 1984. - С.145-155.

18. Шагдаров Л.Д. Формирование и развитие национального языка у бурят // Исследования по истории монгольских языков. - Улан-Удэ, 1993. - С.11-37.

\section{Reference}

Badmaev 2011 - Badmaev, AG 2011, Strukturnyj analiz territorial'noj differenciacii rasseleniya i hozyaj-stva Respubliki Buryatiya: Dissertaciya na soiskanie uchenoj stepeni kandidata geografiche-skih nauk, Ulan-Udeh. (Badmaev, AG 2011, Structural analysis of territorial differentiation of settlement and agriculture of the Republic of Buryatia: The dissertation on competition of a scientific degree of candidate of geographical Sciences, Ulan-Udeh). (in Rus).

Bertagaev 1968 - Bertagaev, TA 1968, Buryatskij yazyk, YAzyki narodov SSSR, T.5. Mongol'skie, tunguso-man'chzhurskie i paleoaziatskie yazyki, Nauka, Leningrad, P.13-33. (Bertagaev, TA 1968, Buryat language, Languages of peoples of the USSR. Vol.5. Mongolian, TungusManchurian and paleo-Asiatic languages, Nauka, Leningrad, P.13-33). (in Rus).

Buraev, SHagdarov 1995 - Buraev, ID, SHagdarov, LD 1995, Buryatskij yazyk, Gosudarstvennye yazyki Rossijskoj Federacii, Academia, Moscow, P.51-59. (Buraev, ID, SHagdarov, LD 1995, Shagdarov Buryat language, Languages of the Russian Federation, Academia, Moscow, P.51-59). (in Rus).

Cydendambaev 1958 - Cydendambaev, CB 1958, Za dal'nejshee razvitie buryat-mongol'skogo literaturnogo yazyka, Sbornik trudov po filologii, Vyp.3, Ulan-Udeh, P.3-11. (Cydendambaev, CB 1958, For the further development of the Buryat-Mongolian literary language, Collection of works on Philology, Issue 3, Ulan-Udeh, P.3-11). (in Rus).

Darbeeva 1997 - Darbeeva, AA 1997, Buryatskij yazyk, YAzyki mira. Mongol'skie yazyki, tungusoman'chzhurskie yazyki, yaponskij yazyk, korejskij yazyk, Izd-vo «Indrik», Mosocw, P.37-51. (Darbeeva, AA 1997, The Buryat language, Languages of the world. Mongolian languages, Tungusic languages, Japanese language, Korean language, Izd-vo «Indrik», Mosocw, P.37-51). (in Rus).

Itogi Vsesoyuznoj perepisi naseleniya 1989 - Itogi Vsesoyuznoj perepisi naseleniya $1989 \mathrm{~g}$. Raspredelenie naseleniya po nacional'nosti i yazyku, lyun', Ulan-Udeh. (The results of the Soviet census of 1989, population Distribution in national STI and language, lyun', Ulan-Udeh). (in Rus).

Hilhanova 2007 - Hilhanova, EhV 2007, Faktory kollektivnogo vybora yazyka $i$ ehtnokul'turnaya identichnost' u sovre-mennyh buryat (diskurs-analiticheskij podhod). Dokt. dissert. Rukopis', Ulan- 
Udeh. (Hilhanova, EhV 2007, Factors of collective choice of language and ethno-cultural identity in contemporary Buryats (discourse-analytical approach): Doc. the dessert. Manuscript, UlanUdeh). (in Rus).

Ho Sun CHkhol 2000 - Ho Sun CHkhol 2000, YAzykovaya situaciya v Rossii i drugih novyh nezavisimyh gosudarstvah byvshego SSSR, YAzyki Rossijskoj Federacii i novogo zarubezh'ya: status $i$ funkcii, EHditorial URSS, Moscow, P.381-391. (Ho Sun CHkhol 2000, Language situation in Russia and other newly independent States of the former USSR, Languages of the Russian Federation and new foreign countries: status and functions, EHditorial URSS, Moscow, P.381-391). (in Rus).

Martin 2002 - Martin, T 2002, Imperiya pozitivnogo dejstviya: Sovetskij Soyuz kak vysshaya forma imperializma?, Ab Imperio. Theory and History of Nationalism and Empire in the Post-Soviet Space. N2, P.55-87. (Martin, T 2002, The affirmative action Empire: the Soviet Union as the highest form of Empire-Lisma?, Ab Imperio. Theory and History of Nationalism and Empire in the Post-Soviet Space, N2, P.55-87). (in Rus).

Mihal'chenko 2009 - Mihal'chenko, VYu 2009, Funkcional'naya tipologiya yazykov Rossii kak chast' sociolingvisticheskoj klassifikacii yazykov mira, YAzyk kak nacional'noe dostoyanie: problemy sohraneniya ling-visticheskogo raznoobraziya: Sbornik trudov Mezhdunarodnoj nauchnoj konferencii. 9-13 sen-tyabrya 2009 g, Izd-vo BNC SO RAN, Ulan-Udeh, P.34-43. (Mihal'chenko, VYu 2009, Functional typology of languages of Russia as part of sociolinguistication classification of the languages of the world, Language as the national heritage: problems of preservation of linguistic diversity: proceedings of the International scientific conference. September 9-13, 2009, Izdvo BNC SO RAN, Ulan-Udeh, P.34-43). (in Rus).

Nacional'nyj sostav i vladenie yazykami; grazhdanstvo 2009 - Nacional'nyj sostav $i$ vladenie yazykami; grazhdanstvo 2009, NIC "Statistika Rossii», Moscow, 946p. (Itogi Vserossijskoj perepisi naseleniya 2002 g.: v 14 t., T.4, Kn1, Federal'naya sluzhba gos.statistiki, Moscow). (National composition and language skills; citizenship 2009, NIC «Statistika Rossii», Moscow, 946p. (The results of the national census 2009: 14 t., T.4, Book 1, Federal'naya sluzhba gos.statistiki, Moscow). (in Rus).

Nacional'nyj sostav i vladenie yazykami, grazhdanstvo 2010 - Nacional'nyj sostav i vladenie yazykami, grazhdanstvo. Itogi Vserossijskoj perepisi naseleniya $2010 \mathrm{~g}$.: v 11 tomah, T.4 v 3 knigah, Statistika Rossii, Moscow. (National composition and language skills; citizenship, Results of the all-Russian population census 2010: in 11 volumes. - Vol. 4 in 3 books, Statistika Rossii, Moscow). (in Rus).

Pis'mennye yazyki mira 2000 - Pis'mennye yazyki mira. YAzyki Rossijskoj Federacii. Sociolingvisticheskaya ehnciklopediya, 2000, Kn.1, Moscow, 656p. (Written languages of the world. Languages Of The Russian Federation. Sociolinguistic encyclopedia, 2000, Book 1, Moscow, 656p). (in Rus).

Problema dvuyazychiya 1998 - Problema dvuyazychiya v svete obshchestvennogo mneniya 1998, Pravda Buryatii, 27 maya. (The problem of bilingualism in the light of public opinion 1998, Truth of Buryatia, 27 maya). (in Rus).

Randalov 2002 - Randalov, YuB 2002, Nauchnoe sociologicheskoe issledovanie po probleme Kompleksnoj programmy "Vozrozhdenie i razvitie nacional'nogo yazyka, nacional'noj kul'tury, tradicij $i$ obychaev buryatskogo naroda», «Buryaad unehn», Ulan-Udeh. (Randalov, YuB 2002, Scientific sociological study on the Comprehensive programme «Revival and development of national language, national culture, traditions and customs of Buryat people», «Buryaad unehn», Ulan-Udeh). (in Rus).

SHagdarov 1984 - Shagdarov, LD 1984, Razvitie buryatskogo literaturnogo yazyka v usloviyah dvuyazychiya, Metodologi-cheskie $i$ filosofskie problemy yazykoznaniya $i$ literaturovedeniya, Nauka, Novosibirsk, P.145-155. (Shagdarov, LD 1984, development of the Buryat literary language in bilingualism, Methodological and philosophical problems of linguistics and literary studies, Nauka, Novosibirsk, P.145-155). (in Rus).

SHagdarov 1993 - Shagdarov, LD 1993, Formirovanie i razvitie nacional'nogo yazyka u buryat, Issledovaniya po istorii mongol'skih yazykov, Ulan-Udeh, P.11-37. (Shagdarov, LD 1993, Formation and development of the national language in Buryats, Research on the history of Mongolian languages, Ulan-Udeh, P.11-37). (in Rus).

Vereshchagin 1969 - Vereshchagin, EM 1969, Psihologicheskaya i metodicheskaya harakteristika dvuyazychiya (bilingvizma), Izd-vo Mosk. un-ta, Moscow, 160 p. (Vereshchagin, EM 1969, Psychological and methodological characteristics of bilingualism (bilingualism), Izd-vo Mosk. un-ta, Moscow, 160 p). (in Rus). 